\title{
LEITORES E LEITURAS DE REVISTAS EM QUADRINHOS: UMA HISTÓRIA VISUAL (ANOS 1930-1950)
}

Comics readers and readings: a visual history (years 1930-1950)

Lectores y lecturas de cómics: una historia visual (años 1930-1950)

IVAN LIMA GOMES ${ }^{I^{*}}$

DOI: https://doi.org/10.1590/S2178-149420210104

'Universidade Federal de Goiás - Goiânia (GO), Brasil.

*Doutor em História pela Universidade Federal Fluminense (igomes2@ufg.br)

(D) https://orcid.org/0000-0001-7873-8484

Artigo recebido em 01 setembro de 2020 e aprovado para publicação em 11 de novembro de 2020. 


\title{
RESUMo
}

As revistas em quadrinhos estabeleceram-se como um novo formato de publicação de quadrinhos nos Estados Unidos durante a década de 1930. Seu consumo introduziu novas práticas e desestabilizou concepções bem consolidadas sobre o lugar social da leitura. Seu impacto nas décadas de 1930 e 1950 se nota em uma série de imagens fotográficas dedicadas a leitores de revistas em quadrinhos. 0 artigo discutirá tais imagens, buscando analisar suas representações enquanto agentes que contribuíram para configurar os sentidos públicos dos quadrinhos naquele contexto. A conclusão aponta para o lugar dos quadrinhos e da visualidade numa história mais ampla da leitura.

PALAVRAS-CHAVE: Quadrinhos; Fotografia; História Visual; História da Leitura.

\begin{abstract}
Comic books were established as a new format for publishing comics in the United States during the 1930s. Their consumption introduced new practices of reading and destabilized well-established conceptions about the social place of reading. The impact of comic books between the 1930s and 1950s can be noted by a series of photographic images dedicated to comic book readers. The article discussed such images, aiming to analyze their representations as agents who contributed to configure the public meanings of comics in that context. The conclusion points to the place of comics and visuality in a wider history of reading.
\end{abstract}

KEYWORDS: Comics; Photography; Visual History; History of Reading.

\section{RESUMEN}

Las revistas de historietas se establecieron como un nuevo formato de edición de historietas en Estados Unidos durante la década de 1930. Su consumo introdujo nuevas prácticas y desestabilizó concepciones bien establecidas sobre el lugar social de la lectura. Su impacto en las décadas de 1930 y 1950 puede percibirse en una serie de imágenes fotográficas dedicadas a lectores de revistas de historietas. El artículo abordará tales imágenes, buscando analizar sus representaciones como agentes que contribuyeron para configurar los significados públicos de los cómics en ese contexto. La conclusión apunta al lugar de los cómics y de la visualidad en una historia más amplia de la lectura.

PALABRAS CLAVE: Historieta; Fotografía; Historia Visual; Historia de la Lectura. 


\section{INTRODUÇÃO: HISTÓRIA EM QUADRINHOS ENQUANTO ESCRITA-IMAGEM}

$\mathbf{C}_{\text {tantes reflexões filosóficas contemporâneas sobre a Modernidade. Em seus estudos sobre }}$ a reprodutibilidade técnica e 0 advento de uma forma revolucionária de fruição estética por meio dela, compôs um rico quadro das transformações vivenciadas pela sociedade capitalista no limiar do século XX. Ele defendia que a Modernidade, com sua atenção às articulações entre a técnica editorial, a fragmentação das experiências e a crise do papel do narrador, favoreceu o surgimento do romance moderno.

Ainda que as histórias em quadrinhos (HQ) não tenham sido objeto de apreciação crítica por parte de Benjamin, algumas das suas considerações sobre outras práticas de leitura que considerava sintonizadas com o estágio de desenvolvimento capitalista então em curso parecem se adequar muito bem às narrativas das HQ. Em Rua de mão única, Benjamin defende que

A atuação literária significativa só pode instituir-se em rigorosa alternância de agir e escrever; tem de cultivar as formas modestas, que correspondem melhor a sua influência em comunidades ativas que o pretensioso gesto universal do livro, em folhas volantes, brochuras, artigos de jornal e cartazes. Só essa linguagem da prontidão mostra-se atuante à altura do momento. (Benjamin, 1987: 11).

Escrita em 1928 sob o título Posto de gasolina, a passagem acima indica que, diante de "comunidades ativas" adeptas de novas práticas de leitura e consumo, outras literaturas, inspiradas em "folhas volantes, brochuras, artigos de jornal e cartazes", devem tornar-se relevantes. Ao contrário da pretensão universalista do livro, a fragmentação da leitura moderna demanda de seus leitores uma interação mais efetiva, estabelecendo vínculos a favor da construção cotidiana de sentidos e sensibilidades. Tal descrição converge para as formas de leitura e consumo de HQ. Seus leitores podem ser caracterizados como membros de "comunidades ativas", exigentes ao ponto de disputarem os sentidos de suas histórias favoritas a cada lançamento, levando seus autores a uma ativa "linguagem da prontidão", sensível às vicissitudes do seu público leitor.

É por isso que Benjamin indica que o livro, em sua "forma tradicional", descansava "oblíquo sobre escrivaninhas" e "acamava-se na impressão". 0 anúncio do declínio do livro fora decretado anteriormente, reconhece Benjamin, por Mallarmé, que teria incorporado "as tensões gráficas do reclame" em sua escrita, bem como pelos experimentos dos poetas dadaístas. Para Benjamin, era inevitável que a escrita fosse "arrastada para as ruas pelos recla- 
mes", pois o leitor moderno, antes de abrir um livro, já tem "sobre seus olhos um tão denso turbilhão de letras cambiantes, coloridas, conflitantes, que as chances de sua penetração na arcaica quietude do livro se tornaram mínimas". Tal "escrita-imagem" demandará uma qualidade de "calígrafos" dos escritores que, então, "renovarão sua autoridade na vida dos povos" (Benjamin, 1987: 27-29).

Ora, mesmo sem menções diretas às HQ, a defesa de uma "escrita-imagem", cujas origens podem ser traçadas à conjunção de novos desenvolvimentos gráficos dos anúncios publicitários e à organização visual da imprensa, soa ilustrativa, para dizer o mínimo. E, a exemplo do que demonstraram autores diversos, como Burrows (2010: 21), Armstrong (2002: 3) e, no Brasil, Süssekind (1987: 29), desde a segunda metade do século XIX a literatura já se mostrara sensível às alterações na sensibilidade promovidas por novas tecnologias e artes técnicas, como a fotografia e o cinema. Os escritores mostravam-se atentos ao novo "horizonte técnico" que se desenhava diante deles. Como sintetizou em 1909 o cronista carioca João do Rio, "aos demais, se a vida é um cinematógrafo colossal, cada homem tem no crânio um cinematógrafo de que o operador é a imaginação" (João do Rio, 2009: 4).

Na trajetória histórica das HQ, a ascensão de novos suportes para a sua difusão contribuiu para o desenvolvimento de novas relações culturais entre HQ e consumidores. Nesse sentido, não é possível pensá-las desencarnadas dos seus meios de difusão, sendo cada um deles etapa fundamental para a consolidação social dos quadrinhos enquanto prática cultural. Nos Estados Unidos, após o seu surgimento nas páginas dos periódicos norte-americanos em fins do século XIX, foi apenas nos anos de 1930 que os quadrinhos finalmente atingiram independência editorial, com a introdução das primeiras revistas em quadrinhos no mercado.

0 impacto cultural causado pela disseminação do formato das revistas em quadrinhos pode ser perscrutado pela análise de uma série de fotografias datadas do período entre o fim da década de 1930 e os primeiros anos da década de 1950. Elas serão objeto de análise deste artigo, de forma a possibilitar uma reflexão histórica sobre as práticas de leitura associadas às revistas em quadrinhos. A série organizada procurou reunir um conjunto de imagens fotográficas dispersas em coleções on-line, tomando como eixo central imagens produzidas pela revista Time \& Life e pelos programas "Farm Security Administration" e "Office of War Information" ${ }^{1}$. 0 diálogo aqui desenvolvido entre imagens produzidas em veículo de mídia e fotografias produzidas por agência de governo dos Estados Unidos aponta para uma análise que, longe de pretender abranger a totalidade de eventuais imagens fotográficas relacionadas às HQ ou mesmo definir o papel da fotografia nesses anos, discute a importância social da revista em quadrinhos para a construção histórica das HQ enquanto prática cultural. Analisadas ao lado de outras fontes que dialogaram diretamente com as revistas em quadrinhos desse pe- 
ríodo, como imprensa, artigos e obras acadêmicas e literárias, as fotografias assumem papel central para a configuração de práticas de leitura específicas para as revistas em quadrinhos.

\section{UM NOVO FORMATO DE EDIÇÃO ENTRA EM CENA}

ntes limitadas ao espaço das páginas de jornal ou dos seus suplementos, as HQ al-
canam autonomia pela sua veiculação em revistas — o que demandava, também, estratégias distintas para a sua distribuição e consumo. Afora iniciativas isoladas, como The Funnies, revista contendo material inédito e lançada entre 1929 e 1930, as revistas em quadrinhos resumiam-se a compilações de material previamente publicado em suplementos de jornais. No geral, serviam como uma espécie de brinde oferecido por syndicates ${ }^{2}$ para reforçar o consumo de outros produtos, prolongando o relacionamento entre quadrinhos e cultura de consumo presente desde fins do século XIX (Gordon, 1998). Tal foi o caso da revista Funnies on Parade. Lançada pela gráfica Eastern Color, continha HQ das distribuidoras Ledger e Bell e serviu, de início, como recompensa aos consumidores de produtos da Procter \& Gamble na troca de alguns cupons. Logo outras companhias adotariam Funnies on Parade como prêmio. A facilidade do seu formato - um tabloide de jornal dobrado ao meio - e o êxito de sua comercialização, ligado a campanhas publicitárias, garantiram novas e expressivas tiragens (Gabilliet, 2010: 8-9). No entanto, as revistas em quadrinhos ainda se encontravam atreladas e dependentes de outros produtos. Se, de início, traziam compilações de antigas histórias publicadas anteriormente nos suplementos de jornais, logo passaram a publicar histórias inéditas, fortemente influenciadas pela literatura pulp, repletas de ação, violência e personagens heroicos (Chambliss e Svitavsky, 2008: 1-33).

0 passo seguinte foi investir nas revistas em quadrinhos como uma mídia viável do ponto de vista comercial, não mais como brinde e sim como principal atrativo para os seus leitores. Uma das muitas conhecidas lendas presentes na história das HQ dá conta de que Max Gaines, um dos vendedores da Eastern Color, convenceu a editora Dell a imprimir 35 mil exemplares da revista Famous Funnies: a Carnival of Comics, estabeleceu o preço de 10 centavos para a publicação e distribuiu os exemplares por bancas e locais de venda de revistas da sua vizinhança numa sexta-feira à noite. Com 64 páginas de tiras publicadas anteriormente em jornais, a tiragem inicial da revista esgotou-se em poucos dias. Seguiram-se novas edições, que, não raro, foram tratadas com certa relutância por alguns dos agentes envolvidos naquilo que Robert Darnton definiu como "circuito de comunicação" (Darnton, 1990: 112). Eram eles patrocinadores, por vezes pouco interessados em anunciar produtos nessas revistas; distribuidores, que se recusaram a trabalhar com elas, tornando inicialmente obrigatória a distribuição direta; e vendedores, que não sabiam como expô-las em suas bancas. Isso fez 
com que várias caixas de Famous Funnies permanecessem intocadas e, em seguida, fossem devolvidas aos seus distribuidores. Tamanhos prejuízos foram revertidos apenas do sétimo número em diante, e o formato logo estaria consolidado: em 1936, oito revistas em quadrinhos já apareciam regularmente, metade das quais publicavam material inédito (Gabilliet, 2010: 8-12; Wright, 2003: 2-4).

Com a ideia de alguns distribuidores de quadrinhos de dobrar um suplemento de jornal e vendê-lo como revista, iniciou-se uma verdadeira transformação nas relações entre HQ e leitores. A solução barata e sem maiores preocupações de adaptar as técnicas de impressão ao novo formato fez com que tais revistas contassem com qualidade sofrível do ponto de vista gráfico. As cores tinham de ser primárias e berrantes para aparecem bem e as letras eram de difícil leitura. Tudo isso levava a uma seleção pouco rigorosa de histórias de qualidade — mesmo porque não eram muitos os que queriam se vincular a tal mídia - que mais aproximavam tais revistas da literatura pulp. De diversão em quatro cores, logo as HQ em revista passaram a ser chamadas de "pesadelos em quatro cores" por jornalistas, pedagogos e outros críticos das limitações editoriais do formato de revistas (Gabilliet, 2005: 1-8). Paralelamente, nascia também a moderna indústria de revistas em quadrinhos, com seu personagem-ícone: Superman, criado em 1933 por Jerry Siegel e Joe Shuster. O personagem só conseguiu tornar-se um sucesso de público quando publicado em revistas; anteriormente, seus autores haviam tentado publicá-lo em tiras, sem sucesso.

\section{REVISTAS EM EXIBIÇÃO}

U ma reflexão sobre a leitura de $\mathrm{HQ}$ baseada em uma série fotográfica deve atentar para as contribuições que os estudos sobre imagens fotográficas fornecem para as relações entre história e fotografia. As fotografias não escapam dos mesmos procedimentos que são sugeridos ao historiador quando empreende o escrutínio crítico de suas fontes, problematizando-as enquanto documento/monumento, conforme sugere Mauad (2008: 37, 42). Fonte de um passado que é flagrado num clique e expressão de relações de força existentes em um dado momento, cada fotografia é o resultado das tensões históricas entre aparatos técnicos e práticas sociais que dotam as imagens fotográficas de sentido, por meio de "certas transações" entre tais forças, no dizer de Tagg (1993: 2-3). Dito de outro modo, seria problemático pretender estabelecer que a série de fotografias relacionadas à leitura de quadrinhos nos anos 1930-1950 permite visualizar as formas como as HQ foram consumidas nesse período. Antes, convém considerar que a fotografia promove a mediação de discursos e perspectivas, ao mesmo tempo em que termina por conformar, ela própria, determinadas visões de mundo (Mauad, 2008: 26, 37). 0 que está em questão, portanto, são os sentidos sociais e histo- 
ricamente presentes num conjunto de imagens fotográficas que tematizam as revistas em quadrinhos enquanto prática cultural.

Tal como as HQ, a imagem fotográfica deve ser entendida como uma prática que involucra em seu ato sentidos, percepções e valores. Para além do caráter autoral que está presente em cada uma delas, destaca-se o que Pierre Bourdieu classificou como "sistemas de valores" subjacentes a diversos grupos postos em relação nas fotografias. Com base na "interiorização de realidades objetivas e correntes", deve-se analisar a construção histórica e social das formas de visualizar o que deve ou não ser visto (Bourdieu, s.d.: 4). Dessa maneira, as representações fotográficas encontram-se em relação com outros discursos sobre as revistas em quadrinhos, tais como filmes, obras literárias, notícias de jornais, além das próprias HQ.

Antes de abordar as imagens fotográficas relacionadas às revistas em quadrinhos, cabe destacar que os quadrinhos publicados sob a forma de suplementos de jornais também foram objeto das lentes dos fotógrafos associados à Farm Security Administration ${ }^{3}$ (FSA). Em fotografias que representavam as moradias da população negra dos Estados Unidos produzidas por Ben Shahn e Marion Post Walcott, a composição da imagem segue orientação comum: uma habitação muito pobre, com poucos móveis e que ocupa boa parte do enquadramento do fotógrafo. Destacam-se as paredes forradas com jornais que aparentam bastante uso, com destaque para os quadrinhos, além de, próximas a eles, crianças com olhar distante em direção à lente do fotógrafo (Figuras 1 e 2).

Por mais que as HQ já contassem com um grau de desenvolvimento da sua linguagem bastante considerável durante os anos 1930, elas ainda eram entendidas como mais uma das muitas seções que compunham um jornal. Por serem os suplementos de quadrinhos produtos da cultura de massas, com suas cores e formas que implicam uma comunicação bastante direta, forrar paredes com eles também lhes confere uma finalidade, na medida do possível, decorativa. Além disso, as fotografias permitem associações entre quadrinhos, cultura de massas e classes populares ${ }^{4}$.

Tal situação parece se alterar com a popularização das revistas em quadrinhos. A visibilidade fotográfica de atividades ligadas a ela, como a disposição em postos de venda, a leitura e as relações entre leitores, permite aventar que algumas características dessa mídia chamaram a atenção de fotógrafos do período ao ponto de merecerem se tornar visíveis através das suas objetivas. Levando em consideração a historicidade do olhar e da produção de sentidos em fotografias, algumas considerações para explicar a presença de tais representações devem ser esboçadas. Um primeiro passo é constatar que as revistas em quadrinhos produzidas a partir de meados dos anos 1930 imprimiram novas questões ao olhar, tanto dos seus leitores quanto daqueles que observavam e interpretavam esse novo fenômeno da 


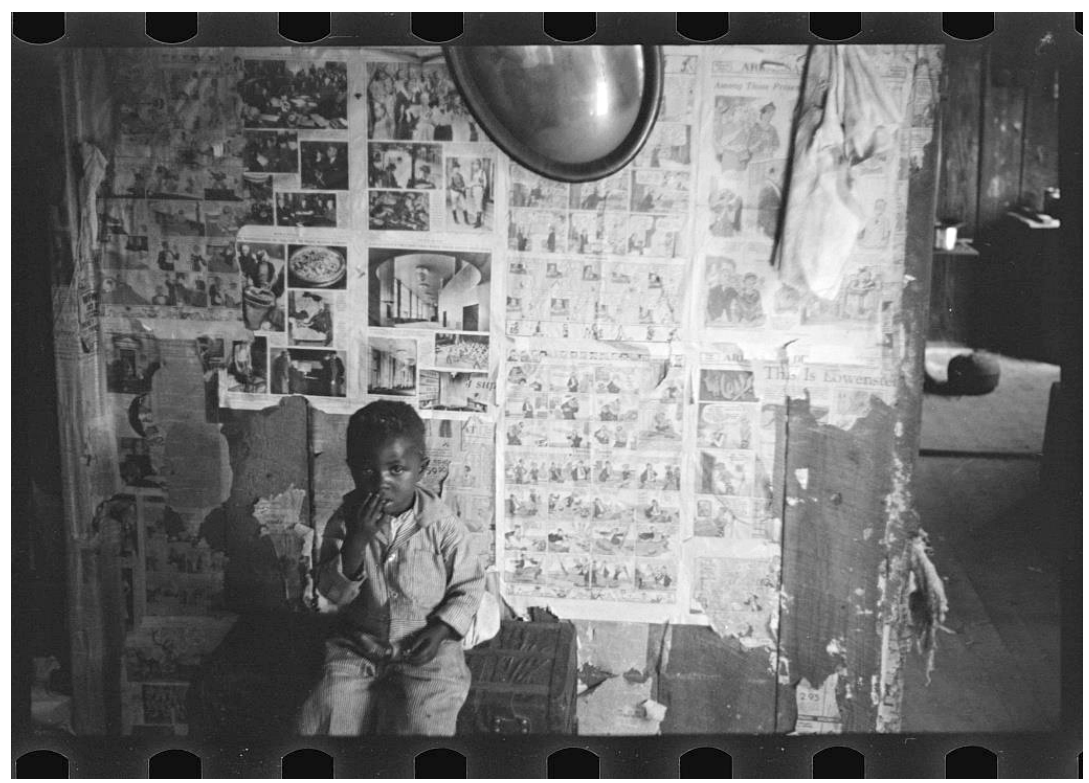

Figura 1 - Ben Shahn. Interior of Negro tenant farmer's home. Little Rock, Arkansas. Outubro de 1935. Disponivel em: <https://www.loc.gov/pictures/resource/fsa.8a16140/>. Acesso em: 22 ago. 2020.

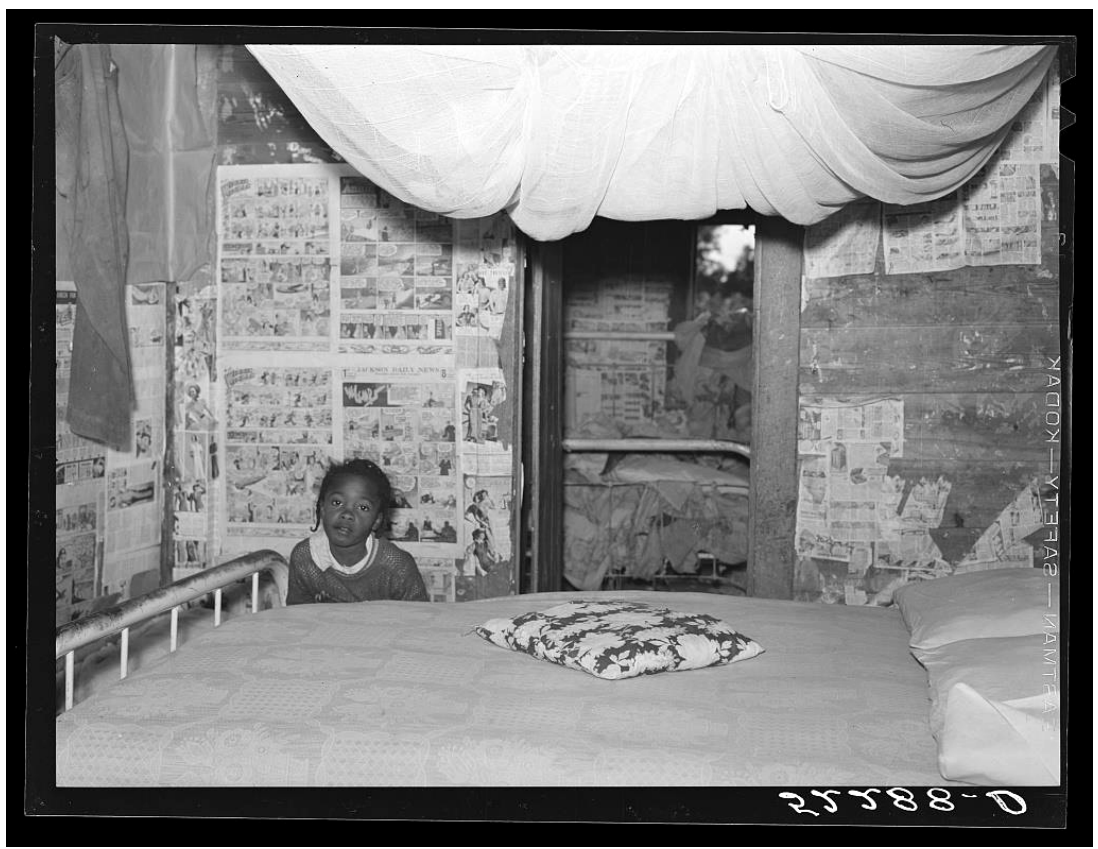

Figura 2 - Marion Post Wolcott. Interior of Negro tenant showing mosquito netting over bed. Mileston Planton, Mississipi Delta, Mississipi. Novembro de 1939.

Disponivel em: <https://www.loc.gov/pictures/resource/fsa.8c10732/>. Acesso em: 22 ago. 2020. 
cultura jovem. Com base nelas, torna-se possível tecer uma série de associações entre as representações tornadas (in)visíveis na imagem fotográfica e, com isso, historicizar as HQ, entendendo-as enquanto resultado da relação entre os diversos agentes que historicamente as constituem e imprimem nelas seus sentidos (Bourdieu, s.d.).

As fotografias dos locais de venda das revistas são preciosos registros da introdução dos quadrinhos no mercado editorial de publicações periódicas e das exigências para a sua comercialização como produto específico. Não obstante o fato de que já eram publicadas desde o século XIX em jornais, a circulação de quadrinhos em revistas não resultaria necessariamente na sua aceitação automática pelos vendedores de bancas de jornal. Em um primeiro momento, muitas delas foram recusadas por eles, não confiantes de que conseguiriam obter algum lucro com aquela "desconhecida arte popular", na expressão de Thierry Groesteen (2004). Um rearranjo dos espaços de venda teve de ser levado a cabo. Entre as fotografias recolhidas, várias destacam os locais de comercialização das revistas em quadrinhos e a sua organização para atrair os olhares dos leitores. As fotografias das Figuras 3 a 5 indicam duas formas possíveis de exposição dos exemplares de revistas em quadrinhos para venda: dispostos lado a lado em estantes ou pendurados (Figura 4), sempre ressaltando as imagens presentes nas capas, ou empilhados em expositores, de forma a destacar os títulos localizados na parte superior das capas.

A profusão de títulos levava à exploração da visualidade nas capas das revistas como estratégia editorial de destaque, que servia para chamar a atenção dos seus leitores e construir uma identidade visual. Por isso, era comum que as revistas do período contassem com títulos que destacavam de alguma forma sua temática — ficção científica, aventuras da selva, aviação — ou suas qualidades, como "maravilhosa", "empolgante" ou "incrível", por exemplo.

0 uso do cabeçalho nas capas das revistas em quadrinhos facilitava a sua disposição no interior dos estabelecimentos comerciais. As publicações podiam ser agrupadas e reconhecidas pelo título que, em geral, indicava o gênero de boa parte das HQ presentes nelas. Com isso, os cabeçalhos deveriam ser diretos e com letras bem destacadas, de forma a destacar as revistas em estabelecimentos comerciais como farmácias, lojas de doces, estações rodoviárias e bancas de jornal. A constituição do "mundo da arte dos quadrinhos" por meio das revistas dependeu, portanto, não somente de desenhistas, roteiristas e editores, mas também das estratégias adotadas para a sua comercialização (Beaty, 2012; Becker, 2008). Tal é a conclusão a que se chega com base nas fotografias; outras fontes podem ser levantadas para reforçar a hipótese.

Numa tira cômica de 1950 de Bugs Bunny (Pernalonga), o enredo brinca com as denominações relacionadas à expressão comic book. Representando um dono de estabelecimento comercial que vende revistas em quadrinhos, o personagem conhecido no Brasil 


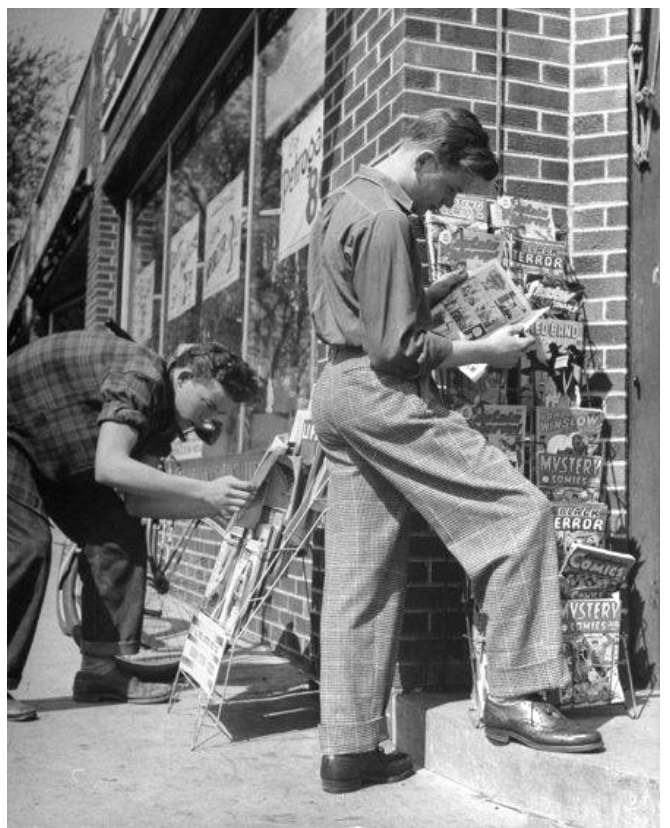

Figura 3 - Nina Leen. Reading comic books at local drug store. Des Moines, lowa, 1945.

Disponível em: <https://api.time.com/wp-content/uploads/2012/07/00637437_nine_leen.jpg?quality $=85 \& w=446>$. Acesso em: 15 ago. 2020.

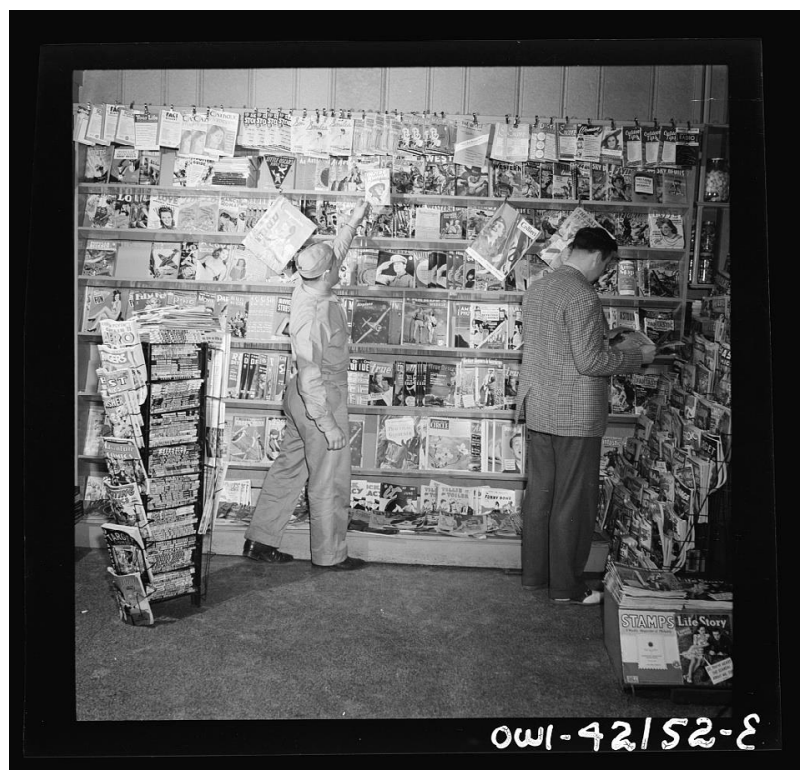

Figura 4 - Charles Fenno Jacobs. Southington, Connecticut. Where Southington folk buy their magazines. Maio de 1942. Disponivel em: <https://www.loc.gov/pictures/resource/fsa.8d35164/>. Acesso em: 22 ago. 2020. 


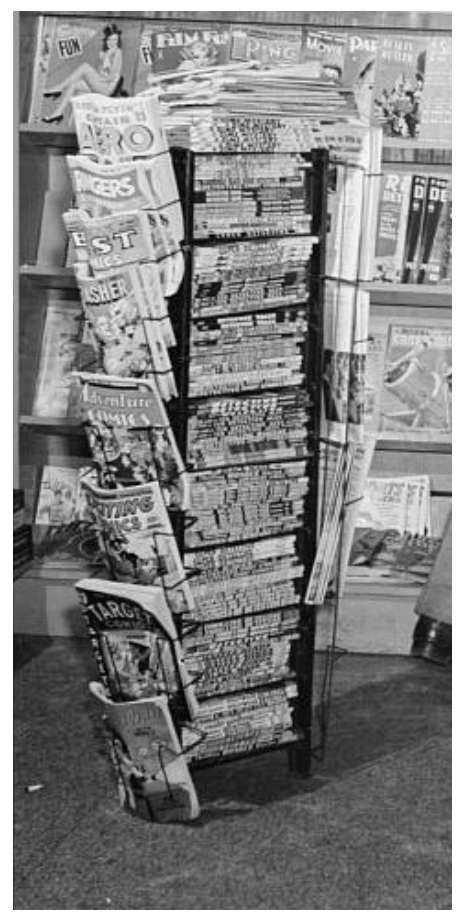

Figura 5 - Detalhe da Figura 4.

como Hortelino expressa insatisfação pelo costume do personagem-título de ler as revistas em quadrinhos e não comprá-las, possivelmente reverberando reclamações reais de outros vendedores. Sob a alegação de que o estabelecimento cobrava uma taxa sobre a leitura dos "livros" — books, da expressão comic books - , Pernalonga responde com tranquilidade que está apenas olhando as imagens, para a fúria do vendedor Hortelino (Warsaw Times, 1950: 14).

Entre os artistas da época, Will Eisner, em sua graphic novel de cunho autobiográfico sobre os primeiros anos da indústria de revistas, destaca a importância da comercialização dessas publicações em bancas de jornal na sua motivação para trabalhar com HQ (Eisner, 2008). Harry Lampert, um dos desenhistas que trabalhavam na revista All-American Comics no ano de 1948, conta que "andava diariamente por várias bancas de jornal, e em cada uma lá estava uma multidão de crianças olhando para os quadrinhos" (Hajdu, 2009: 103). Quanto aos leitores, antes de atuar profissionalmente na área, Martin Thall descreve suas idas diárias às bancas de jornal em busca de revistas em quadrinhos (Hajdu, 2009: 37). Nomes importantes da indústria dos quadrinhos sabiam do papel estratégico da boa distribuição e exposição das revistas. Gabilliet argumenta que o sucesso das primeiras publicações ligadas à editora Detective Comics deu-se menos em função da qualidade narrativa das HQ publicadas 
por ela e mais pela racionalização, extensão e mesmo a criação de canais de distribuição das revistas adotadas pela editora. Sob as mãos de Harry Donenfeld e Jack Liebowitz, suas revistas espalharam-se pelos Estados Unidos e venceram a resistência de bancas de jornal, farmácias e outros lojistas, promovendo uma mudança no perfil do público leitor de impressos, que passou a incorporar as revistas em quadrinhos ao seu repertório de leituras (Gabilliet, 2010: 16-17).

Outros indícios podem ser encontrados na revista Newsdealer, publicação voltada a jornaleiros e varejistas que comercializavam revistas e jornais. Ela dedicou um número especial de 1948 às revistas em quadrinhos. Na contracapa, uma ilustração de Superman agradece a eles pela venda de 101.722.107 exemplares de Superman DC Comics no ano anterior - o que permitiu que, no conjunto, os varejistas lucrassem US\$2.543.052,67. Ao lado de artigos variados envolvendo as revistas em quadrinhos, de forma a reforçar a sua comercialização pelos varejistas, chama atenção o amplo destaque dado ao tema da exposição das revistas: há anúncios de venda de expositores de comic books dos mais diversos tipos e tamanhos, exemplos de expositores de revistas em quadrinhos que conseguem vender mais graças à sua "eficiência" e até uma HQ ilustrando como deveria ser a comercialização de quadrinhos (Figura 6).

Para a Newsdealer, uma exposição ordenada de revistas em quadrinhos como mostra a Figura 7 garantia lucros para toda a indústria.

A exposição de revistas em quadrinhos também foi representada numa obra literária que descreve as transformações sofridas pelos Estados Unidos naqueles anos. A certa altura de The Air-Conditioned Nightmare, obra publicada originalmente em 1945 e baseada nas viagens que o escritor norte-americano Henry Miller realizou pelos Estados Unidos em fins dos anos 1930, ele descreve o contato de um jovem leitor com a miríade de publicações em quadrinhos então dispostas à venda:

Havia uma série infindável de revistas rotuladas como "Quadrinhos" na prateleira de baixo, pouco acima da cabeça dele. Ele passou pela fila toda, lendo os títulos devagar: Planet, Heroic, Thrilling, Speed, Smash, Jungle, Exciting, Fight, Wings, Sarting, True, Magic, Wonderful etc. etc. - uma variação aparentemente inexaurível sobre o mesmo tema (Miller, 2006: 212).

O episódio acima teria ocorrido em um bar, local pouco usual, à primeira vista, para 0 consumo de revistas em quadrinhos por jovens - e que, na narrativa de Miller, agrega uma série de sentidos pejorativos ao formato e, por conseguinte, ao próprio garoto. Por ora, cabe destacar que a produção massiva e a alta demanda possivelmente levaram à penetração do comércio de revistas em quadrinhos em outros espaços para além da banca de jornal. Tanto na Figura 7 quanto na passagem de Miller, os títulos das revistas são destacados pela arrumação, o que certamente servia também para atrair leitores para as revistas em estabelecimentos 


\section{THEN and NOW}

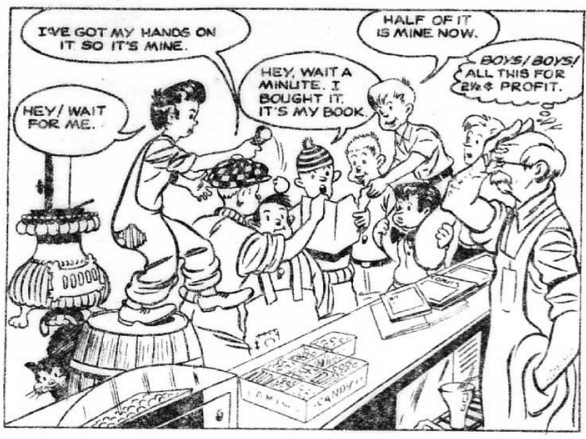

by Lloyd Jacquet Studios

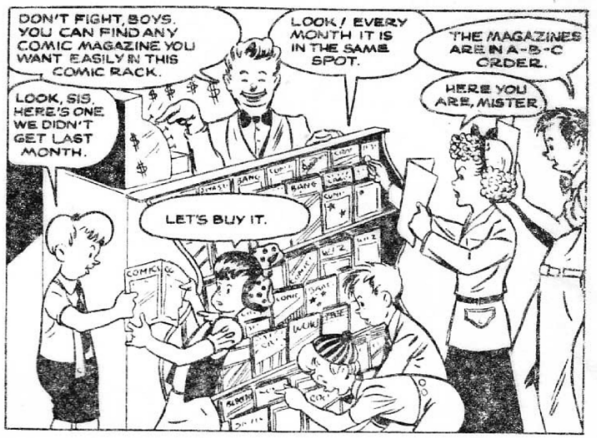

Figura 6 - Tira cômica Then and Now, creditada a "Lloyd Jacquet Studios" Fonte: Newsdealer (jun. 1948: 9).

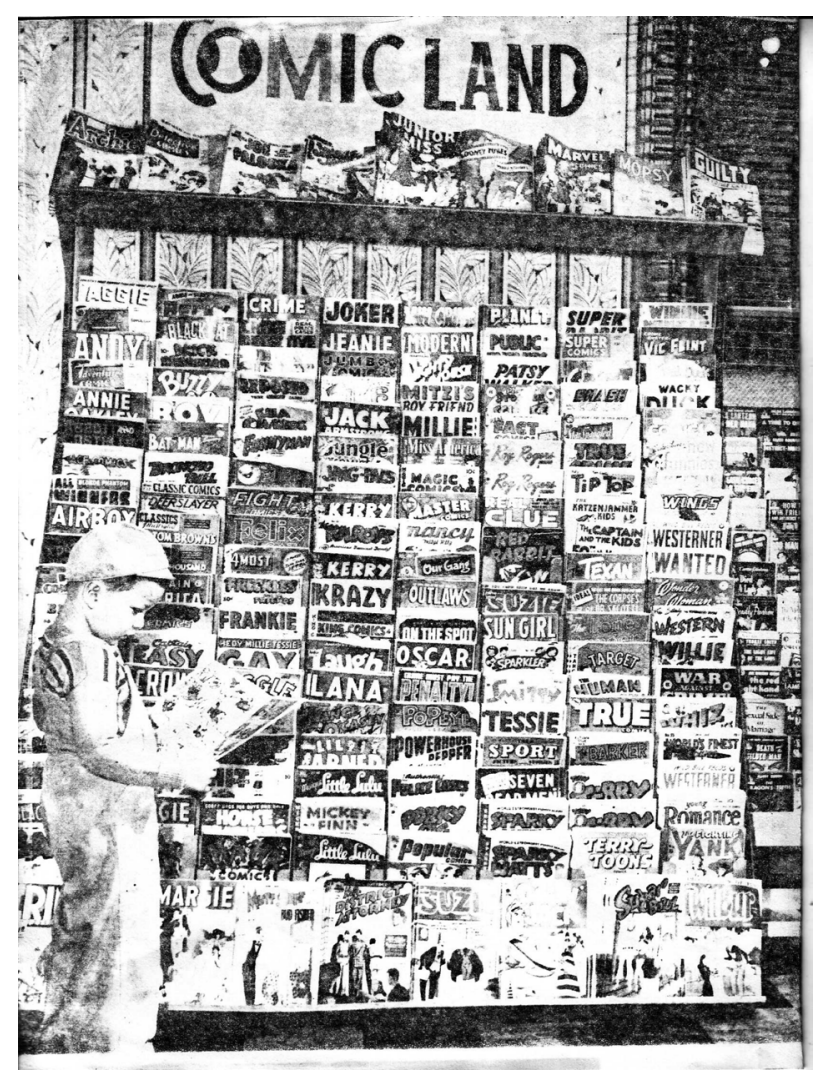

Figura 7 - Fotografia com estante expositora de revistas em quadrinhos e um jovem leitor. Sem créditos. Fonte: Newsdealer (1948: 12). 
comerciais que as dispunham de forma a esconder eventuais capas violentas ou consideradas inadequadas ao público jovem. Mesmo Fredric Wertham, psiquiatra que se tornou famoso nos anos 1950 por suas pesquisas sobre os malefícios causados pela leitura de revistas em quadrinhos sobre as mentes dos jovens leitores, não deixou de atentar para isso (apud Lepore, 2014: 268).

\section{UMA COLETIVIZAÇÃO DA LEITURA}

s imagens fotográficas que retratam a exposição de revistas em quadrinhos para a sua
comercialização também apontam para as maneiras como elas eram compreendidas em relação a outras publicações impressas do período. Ainda que para Henry Miller elas representassem uma "variação inexaurível sobre o mesmo tema", as revistas em quadrinhos podem ser divididas em diversos gêneros narrativos: aventuras na selva, $\mathrm{HQ}$ de detetive, de suspense e de terror, além daquele que pode ser considerado como verdadeira invenção desse formato - o gênero super-heroico, cujo modelo se encontra na primeira edição de Action Comics, com a estreia da HQ Superman. As revistas em quadrinhos pareciam reproduzir em suas páginas parte desse caleidoscópio de impressos que configurava uma banca de jornal, sendo comum encontrar, em uma mesma revista em quadrinhos, HQ de gêneros tão distintos como faroeste, aventuras no espaço, detetives, tiras infantis com personagens antropozoomórficos ou infantis. Com isso, as revistas ramificavam-se e procuravam incorporar o maior número possível de temas e, por conseguinte, leitores.

Outro aspecto presente nas imagens fotográficas das revistas em quadrinhos relaciona-se com a representação da infância. Uma das características dos anos 1930 foi, segundo Bradford Wright, a criação de espaços de convivência próprios para os jovens diante das mudanças sociais que ocorriam nos Estados Unidos. A combinação de reformas educacionais com os elevados índices de desemprego que atingiram a população norte-americana levou a um aumento do tempo de permanência dos jovens em escolas nesse período. Com isso, eles passavam mais tempo juntos e adquiriam uma "consciência geracional" em relação a adultos e responsáveis, mediada pelo consumo de produtos específicos, entre os quais os quadrinhos (Wright, 2003: 26-27). Algumas fotografias parecem reforçar a leitura dos quadrinhos como atividade realizada coletivamente.

Com um enquadramento que demonstra bom domínio técnico do fotógrafo, a imagem fotográfica da Figura 8 registra a leitura coletiva de revistas em quadrinhos por um grupo de garotos. Sentados em uma escada, cada um dedica-se à leitura individual de uma revista. Não há informações sobre qual publicação leem ou mesmo se todas pertencem à mesma série ou ao mesmo número. Independentemente disso, a imagem produzida por John Gutmann parece 


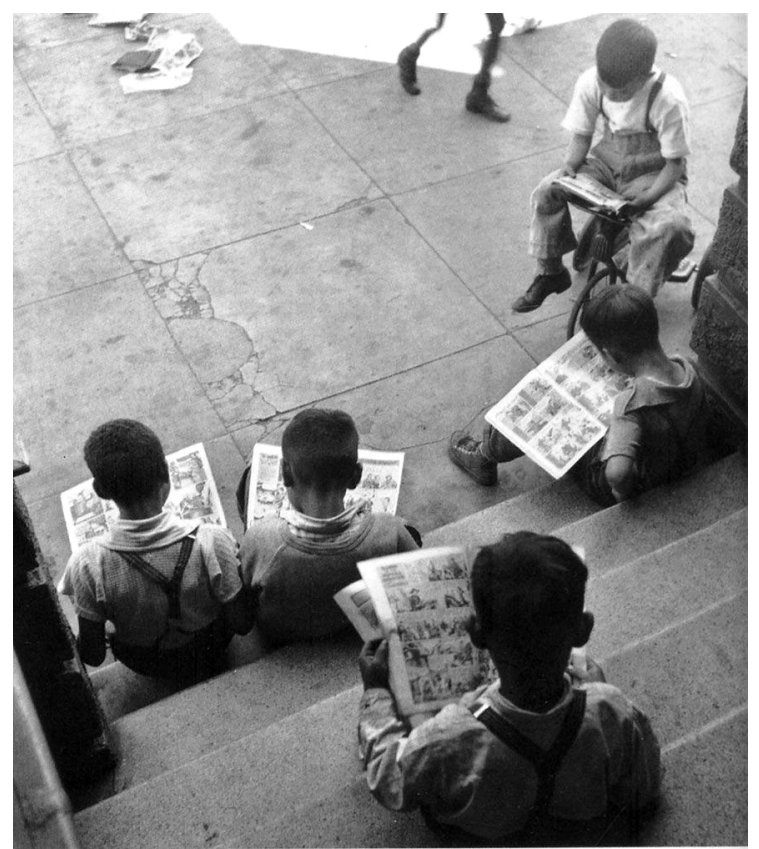

Figura 8 - John Gutmann. Kids reading comics. San Francisco, $1938^{5}$.

Disponível em: <https://br.pinterest.com/pin/748019819347086662/>. Acesso em: 20 out. 2020.

capturar o nascimento da cultura dos comic books e dos imaginários produzidos coletivamente com base na leitura — o sucesso da HQ Superman e das revistas em quadrinhos data do mesmo ano da fotografia. Gutmann, um judeu emigrado da Alemanha para os Estados Unidos em 1933, era um entusiasta do modo de vida norte-americano consumista e contraditório. Diante da massificação da indústria dos comics, Gutmann parece encontrar satisfação na representação fotográfica da cultura das revistas em quadrinhos pelo seu interesse na "invasão do visual pelo textual", tema que Krauss considera fundamental para a fotografia do entreguerras (Krauss, 1982: 100). De acordo com a pesquisadora da imagem, a obra de Gutmann representa a realidade transformada em "imagens falantes" (Krauss, 1982: 91 103). Nada seria mais próximo disso do que a interação entre imagem e texto presente nas HQ nos balões de fala.

Quase 15 anos após a fotografia de Gutmann, Ralph Morse, reconhecido fotógrafo da revista Time, enquadraria a leitura de revistas em quadrinhos por um grupo de garotos (Figura 9). 0 cenário agora é outro: 1952, Guerra Fria, combate ao comunismo, e as revistas em quadrinhos indicavam os primeiros sinais de cansaço. Em meio à campanha para a presidência 


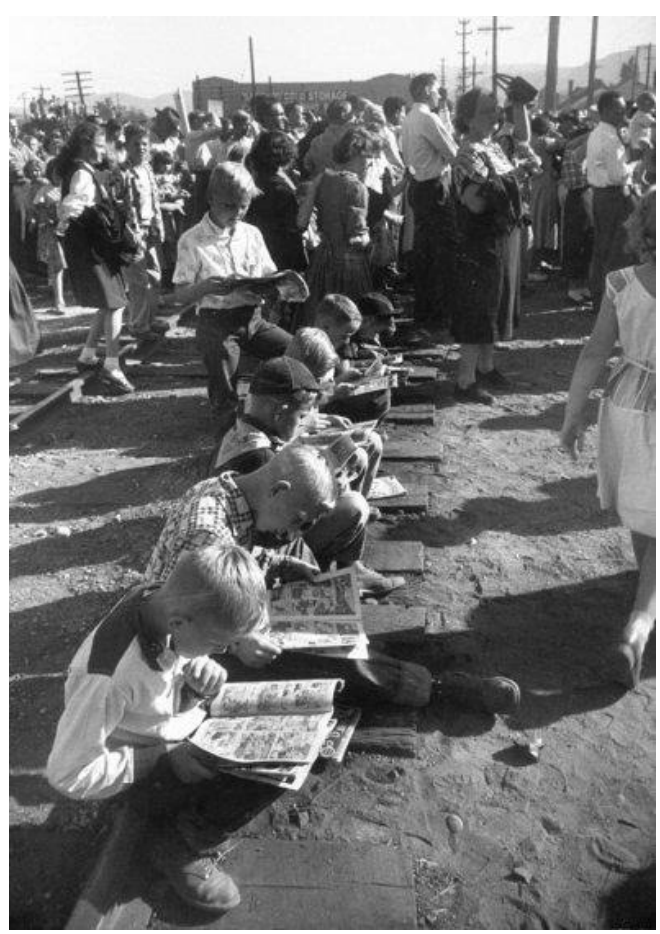

Figura 9 - Ralph Morse. Small boys read comic books during a speech by Dwight Eisenhower in Montana, 1952. Disponível em: <https://api.time.com/wp-content/uploads/2012/07/00794862_ralph_morse.jpg?quality $=85 \& w=395>$. Acesso em: 15 ago. 2020.

de Dwight Eisenhower, a fotografia parece indicar que, a despeito de tudo isso, as crianças continuavam sendo apenas crianças, mais preocupadas com as últimas aventuras e situações dos seus personagens favoritos.

A mudança nos hábitos de leitura introduzidos pelas revistas em quadrinhos foi destacada em A multidão solitária, obra escrita por David Riesman, Nathan Glazer e Reuel Denney e publicada originalmente em 1950. Trata-se de um dos primeiros esforços críticos para refletir sobre o do papel dos meios de comunicação de massa na sociedade norte-americana após a Segunda Guerra Mundial. A obra desvela um quadro da sociedade norte-americana, retratando o consumo em massa de uma ascendente classe média, cuja orientação social passa a ser regida pelo que o outro possui e consome, em vez de pela coesão baseada em normas tradicionais ou da educação escolar (Riesman, Glazer e Denney, 1995).

0 livro é farto em referências às HQ e, especialmente, aos comic books, dando amplo destaque ao papel que eles teriam tido na transformação das relações sociais nos Estados Unidos. Ao tratar das práticas de leitura, os autores estabelecem que: 
Entretanto, talvez a mudança mais importante seja a mudança da situação em que a audição e a leitura ocorrem. Em contraste com o leitor solitário da época da introdireção, temos hoje o grupo de crianças deitadas no chão, lendo e trocando estória em quadrinhos e preferências entre estas [...]. Quando o ler e o ouvir não são em comum de fato, tendem a sê-lo em sentimento: há quase sempre consciência onipresente do grupo cômpar. Assim, a fã do Super-homem, mencionada no início do capítulo, não pode permitir-se a identificação com o Super-homem — os outros a considerariam boba - ao passo que não a julgariam boba por acreditar que voar é importante. (Riesman, Glazer e Denney, 1995: 165).

A coletivização da leitura dá-se, portanto, não apenas pela interação entre vários leitores durante 0 ato da leitura de quadrinhos, mas também pela presença de várias revistas em um mesmo espaço de leitura. Vendidas a um preço que permitia o acesso do público leitor jovem, que crescia nos anos de New Deal e no marco dos esforços de guerra, as revistas eram produtos de baixa qualidade geral e desacreditadas por alguns representantes de pais e educadores, reforçando a segmentação e a autonomia da leitura de grupo. Somando-se a isso o caráter ativo presente na leitura de quadrinhos - que requer um leitor integrado à narrativa ao ponto de engajar-se para preencher lacunas entre quadros e, assim, dar conta da serialidade e do caráter "aberto" da narrativa das HQ (Postema, 2013) —, resulta um convite a uma leitura fragmentada, repleta de intervenções e de trocas, por vezes permitindo comentários sociais repletos de ironia e crítica pelos fotógrafos.

0 predomínio de leitores do sexo masculino nas imagens fotográficas deve ser posto em questão mediante outras fontes. 0 que se costuma dizer é que a indústria de revistas em quadrinhos do período era feita de garotos para garotos. Por isso o êxito de quadrinhos de super-heróis, de aventuras na selva, de guerra e de faroeste, mais próximos às expectativas de leitura de meninos e adolescentes do sexo masculino. Em livro de 1965, o cartunista Jules Feiffer traça suas memórias dos primeiros anos de publicação das revistas em quadrinhos e chega ao ponto de dizer que não se lembra de meninas as lendo $0^{6}$. Isso explicaria e justificaria a inexpressiva presença de super-heroínas em HQ com longa duração (Robbins, 2013: 54) ${ }^{7}$.

Pensando as revistas em quadrinhos durante o período 1930-1950, tais informações devem ser nuançadas. Em pesquisa sobre o perfil dos leitores desse tipo de revistas de 1944, observa-se que a leitura abrangia os sexos masculino e feminino até idades acima dos 30 anos. Com preços entre 10 e 15 centavos, em média, meninos e meninas consumiam grandes quantidades delas. Pesquisas de mercado da época apontam para isso: uma entidade norte-americana de pesquisa de mercado constatou, em 1944, que cerca de 70 milhões de pessoas liam revistas em quadrinhos, de acordo com a disposição etária apresentada na Tabela 1. 
Tabela 1 - Leitores de revistas em quadrinhos em 1944.

\begin{tabular}{|c|c|c|}
\hline IDADE (ANOS) & SEXO MASCULINO (\%) & SEXO FEMININO (\%) \\
\hline 06 a 11 & 95 & 91 \\
\hline 12 a 17 & 87 & 81 \\
\hline 18 a 30 & 41 & 28 \\
\hline Acima de 30 & 16 & 12 \\
\hline
\end{tabular}

Fonte: Tabela elaborada com base em dados disponibilizados por Zorbaugh (1944: 193-194) e Lopes (2009: 22).

Na edição de 1948, a revista Newsdealer publicou uma pesquisa realizada pela editora Fawcett Comics. Não há maiores evidências científicas nos dados publicados para os leitores de Newsdealer, varejistas que deveriam ser convencidos da importância da boa exposição das revistas em quadrinhos. Sobre a pesquisa, conclui-se que meninos liam mais quadrinhos do que meninas, principalmente entre 10 e 17 anos, quando costumavam ler em torno de 12 revistas por mês. Porém, o sexo feminino consumia quadrinhos com alguma regularidade, chegando a ultrapassar os homens entre 26 e 35 anos (Newsdealer, 1948: 18). Dessa forma, a revista procurava estimular os varejistas a direcionar os quadrinhos aos pais e mães dos jovens leitores, consolidando a venda do produto e atendendo à tendência de direcionar obras de determinados gêneros e com expressivas tiragens, como revistas em quadrinhos de romance, voltadas para o público feminino (Benton, 1989).

A Figura 10 registra o momento de intimidade de uma leitora de quadrinhos acompanhada de seu cão. Obra de Charles "Teenie" Harris, fotógrafo reconhecido pelo montante de trabalho produzido com a comunidade afro-americana e trabalhadora de Pittsburgh, nela se veem revistas em quadrinhos ao lado de jornais e publicações de romances e crimes classificadas como literatura pulp. A foto é representativa de etapas importantes da construção das HQ enquanto meio de expressão, afinal, é tributária tanto da expansão da imprensa diária $\bigotimes$ e das disputas editoriais para a expansão do público consumidor de periódicos, incluindo o infantil - quanto de um modelo narrativo marcado por suspense, aventuras fantásticas e heróis fantasiados, caro ao formato dos pulps. A presença de revistas em quadrinhos ao lado de tantas outras publicações efêmeras contribuiu, por sua vez, para torná-las um produto descartável que, paradoxalmente, alimentou o imaginário dos seus leitores por gerações.

\section{DO LAZER À GUERRA:}

\section{LER REVISTAS EM QUADRINHOS NO FRONT}

A seu modo, as revistas em quadrinhos também tiveram papel relevante na Segunda 


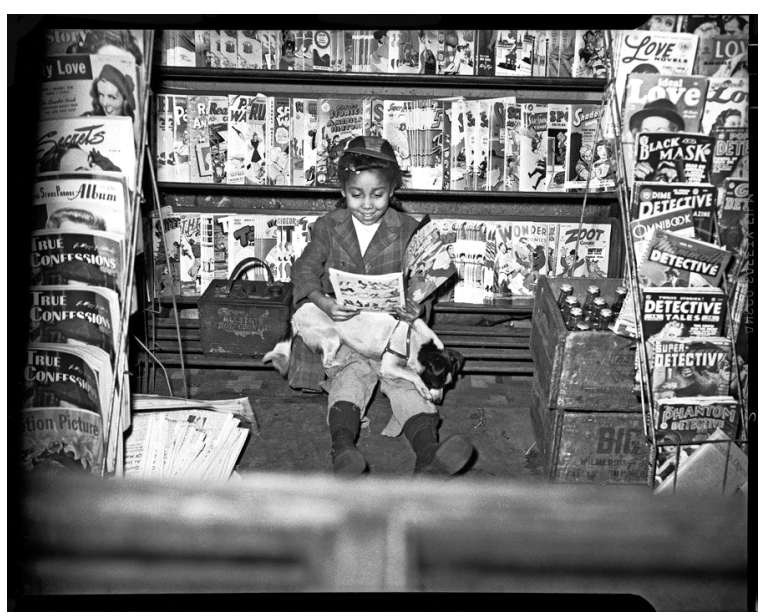

Figura 10 - Charles "Teenie" Harris. Girl reading comic book in newsstand. Pittsburgh, Pensilvania, 1947. Disponivel em: <https://carnegiemuseums.org/magazine-archive/2011/fall/article-291.html>. Acesso em: 22 ago. 2020.

hos de "era de ouro" dos comics. 0 engajamento ocorreu de várias formas. Em relação ao conteúdo, destaca-se a produção de HQ com personagens e temas diretamente relacionados ao conflito. Tornaram-se famosas as histórias em que nomes como Hitler, Mussolini e Hirohito são esmurrados e presos por super-heróis e outros personagens de HQ. As revistas também faziam pedidos por bônus de guerra e até mesmo sugeriam aos leitores que doassem duas revistas após terminarem de lê-las, de modo a contribuir com os esforços de guerra e evitar o aumento do custo do papel. Além disso, inúmeras revistas foram enviadas aos soldados em batalha. Podemos imaginá-las sendo lidas em momentos de ócio, entre uma batalha e outra (Figuras 11 e 12). De um jeito ou de outro, a indústria de revistas em quadrinhos alinhava-se, dentro e fora do território norte-americano, aos ideais dos Aliados e, com isso, consolidava-se do ponto de vista editorial.

A relação entre HQ e o front de batalha da Segunda Guerra Mundial deve ter sido marcante para editores, soldados e fotógrafos, pois, tão logo se iniciaram as primeiras movimentações relativas à Guerra da Coreia, novas imagens fotográficas de leitores de HQ no front de batalha mereceram atenção por parte de fotógrafos (Figura 13).

Perante a diversidade de títulos presentes nas fotografias analisadas aqui, chama atenção a pouca representatividade das revistas de super-heróis nas mãos dos leitores, o que parece ser indício do declínio que o gênero narrativo super-heroico viria a sofrer nos anos seguintes à Segunda Guerra Mundial. Se, em 1945, os leitores poderiam encontrar 33 revistas de super-heróis no mercado, os números sofreram queda nos anos seguintes: 26 em 1946, 19 


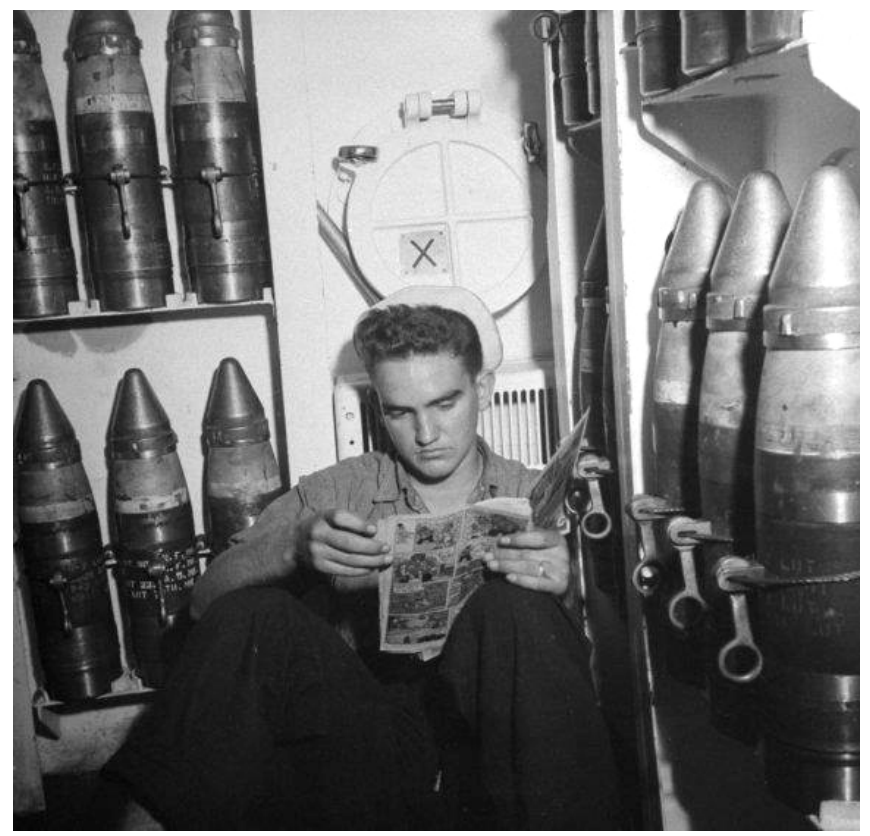

Figura 11 - Thomas McAvoy. A sailor reads a comic book aboard the USS Dora in 1942.

Disponível em: <https://api.time.com/wp-content/uploads/2012/07/00578665_thomas_mcavoy.jpg?quality $=85 \& w=577>$. Acesso em: 15 ago. 2020.

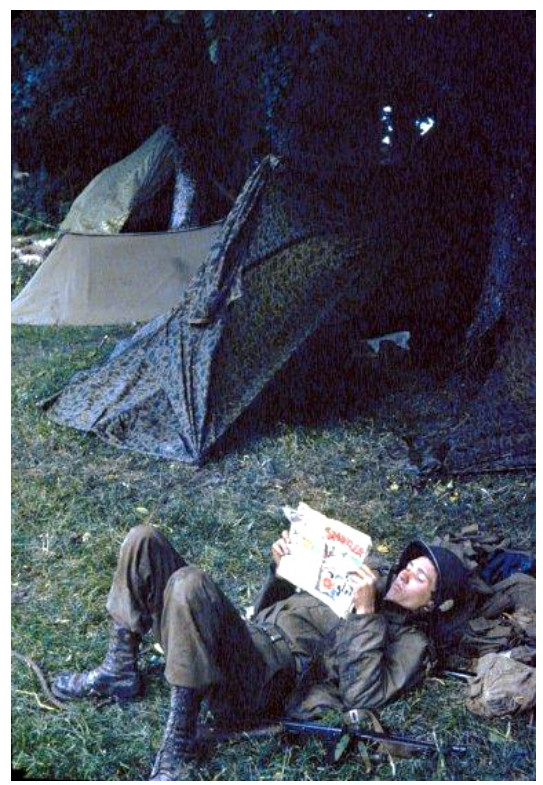

Figura 12 - Frank Scherschel. Private Ernest Dandou reads a comic book at paratrooper camp, Georgia, 1944. Disponível em: <https://api.time.com/wp-content/uploads/2012/07/1150758_frank__scherschel.jpg?quality $=85 \& w=381>$. Acesso em: 15 ago. 2020 . 


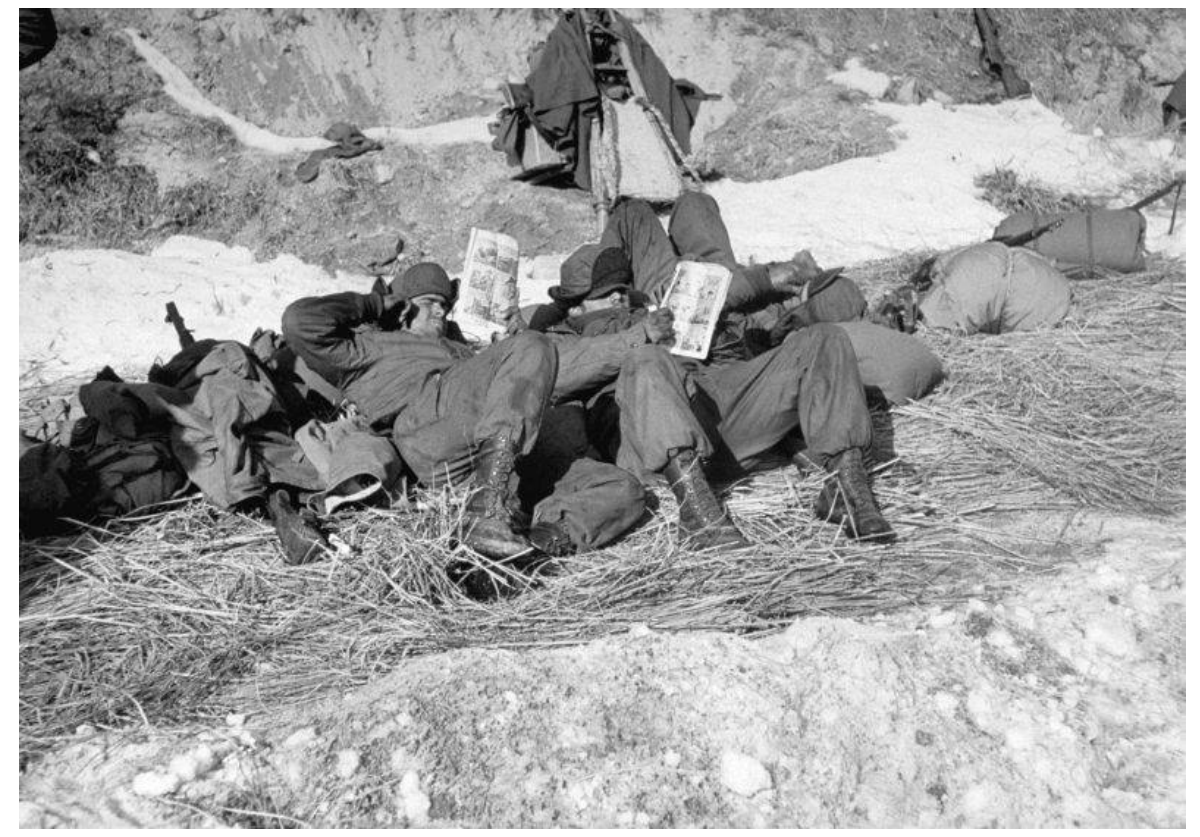

Figura 13 - John Dominis. American troops read comic books during the Korean War, 1951. Disponivel em: $<$ https://api.time.com/wp-content/uploads/2012/07/00727915_john_dominis.jpg?quality=85\&w=795>. Acesso em: 15 ago. 2020.

em 1947, 14 em 1948, oito em 1949, quatro no biênio 1950-1951 e apenas três títulos entre 1952 e 1957 (Gabilliet, 2010: 34).

Uma conhecida interpretação para o declínio dos super-heróis trata mais uma vez de submetê-los à dinâmica geral da sociedade de então: exaurida após anos de conflitos externos e internos, ela não precisaria mais de heróis encapuzados para defendê-la do inimigo nazifascista. Com isso, os super-heróis não resistiram às crescentes críticas de setores conservadores da sociedade norte-americana e o gênero esgotou-se. Tal avaliação soa correta, mas apenas na medida em que aponta para a eventual saturação das narrativas de super-heróis produzidas em escala exponencial durante a primeira metade dos anos 1940 em relação a outros gêneros de revistas em HQ que cresciam paralelamente. Podemos supor que o público leitor formado ao longo dos anos certamente amadureceu e passou a ser mais exigente em suas leituras, demandando enredos mais variados e com melhor tratamento gráfico.

A essa possivel perda de interesse, Gabilliet introduz questões do âmbito editorial que contribuem para uma análise mais complexa da questão. 0 fim da Segunda Guerra Mundial teria surpreendido também os editores das revistas que, em alguns casos, contavam 
com um armazenamento de um ou dois anos de histórias com super-heróis envolvidos de alguma forma com o conflito. Elas passaram a não mais dialogar com a realidade e ficaram datadas. A associação entre super-heróis e a guerra mundial era clara, ao ponto de editores terem antecipado a sua derrocada: em 1948, após a saída de Sheldon Mayer como editor da DC Comics, responsável pela linha de super-heróis, nenhum dos editores remanescentes fez qualquer objeção ao direcionamento da editora a outros gêneros que também chamavam a atenção do público - romance, crime, revistas com personagens adolescentes ou animais antropozoomórficos; a Marvel Comics substituiu seus títulos de super-heróis por revistas em quadrinhos de romance (Gabilliet, 2010: 34).

No lugar dos super-heróis ambientados na Segunda Guerra Mundial, cada vez mais surgiam revistas em quadrinhos com personagens e enredos que procuravam identificação direta com os sentimentos e medos dos seus leitores - uma mistura perigosa para alguns.

\section{CONCLUSÃO}

década de 1950 intensificou os temores quanto aos eventuais danos causados pelas
revistas em quadrinhos nas mentes dos jovens leitores. No clima de anticomunismo e de moralização crescente vivido pelos Estados Unidos de então, as revistas em quadrinhos passaram por escrutínio público e foram alvo de debates acalorados entre congressistas, artistas e editores. Trata-se de uma etapa importante da história das HQ e que, entre discussões apaixonadas e análises mais cuidadosas, já foi bastante discutida na bibliografia, não cabendo alongarmo-nos aqui (Beaty, 2005).

Mais interessante pode ser abordar o debate público sobre os malefícios da leitura de revistas em quadrinhos desde uma história mais ampla da leitura, em que tais impressos representavam uma via de acesso a práticas letradas localizadas fora de cânones estabelecidos. Na esteira do New Deal, encontrava-se consolidada desde os anos 1930 uma orientação para a leitura que a tomava como instrumento de formação e controle social. Pensada enquanto atividade "positiva e totalmente útil", pautava-se por padrões que se baseavam na autoridade da tradição (Petrucci, 1999: 208).

Nos marcos de um século em que a massificação da leitura acompanhou uma bibliodiversidade que introduz novos leitores e práticas ao ato de ler, as revistas em quadrinhos permitem uma entrada original para a história da leitura na era contemporânea. 0 caráter ativo dessa prática, já antecipado no século XIX com a produção industrial e o barateamento dos livros, intensifica-se: na rua, em transportes públicos ou no front de guerra, em pé ou deitado, o leitor de revistas em quadrinhos não respeita convenções de tempo e espaço para realizar a leitura, ao ponto de esta poder ser representada em inúmeras imagens fotográficas. 
O poeta italiano Eugenio Montale apontou, em 1961, as transformações nos modos de ler daqueles anos:

Em particular — observava - leem-se sempre menos livros enquanto é bastante alto o número de leitores de folhas periódicas, jornais, revistas, cartazes, murais e outros impressos. Mas os leitores de publicações volantes, diárias, não leem: veem, olham. Olham com uma atenção de histórias em quadrinhos mesmo quando sabem ler realmente; olham e jogam fora. (Montale apud Petrucci, 1999: 217).

Tais transformações dão-se pelo contato com uma linguagem nova e sua fruição estética, linguagem esta que reafirma o primado do olhar como determinante para a experiência moderna. Não por acaso, as imagens em revista chamaram tanto a atenção de jornalistas, fotógrafos e educadores; em última instância, elas mobilizavam corpos e promoviam novas formas de apreender a realidade e posicionar-se perante o mundo. Passagem ilustrativa quanto às formas de ler HQ é contada pelo também escritor italiano Ítalo Calvino, que considera fundamental a leitura de comics adaptados - Happy Hooligan, Katzenjammer Kids, Felix the Cat e outros, com supressão de balões de fala e sua substituição por legendas — para levá-lo a "pensar por imagens":

Não largava aquelas revistinhas que minha mãe havia começado a comprar e a colecionar ainda antes de eu nascer e que mandava encadernar a cada ano. Passava horas percorrendo os quadrinhos de cada série de um número a outro, contando para mim mesmo mentalmente as histórias cujas cenas interpretava cada vez de maneira diferente, inventando variantes, fundindo episódios isolados em uma história mais ampla, descobrindo, isolando e coordenando as constantes de cada série, contaminando uma série com outra, imaginando novas séries em que personagens secundários se tornavam protagonistas. (Calvino, 1990: 109).

As preocupações quanto às leituras perigosas — e os leitores perigosos — são um capítulo fundamental para a história da leitura. Devem servir, hoje, de alerta sobre as perseguições sofridas por obras literárias, graphic novels e livros infantojuvenis que, acusados de promoverem o "homossexualismo" e outros valores antagônicos a certa moral conservadora, são alvo de censura e objeto de instrumentalização política.

Conflitos de interesse: nada a declarar.

Fonte de financiamento: nenhuma. 


\section{NOTAS}

1 Respectivamente, Time \& Life; reproduções disponiveis em: <https://time.com/22575/classic-comics-in-praise-of-an-american-art-/>. Acesso em: 23 out. 2020. E Farm Security Administration/Office of War Information Photograph Collection; reproduções disponíveis em: <http://www.loc.gov/pictures/collection/fsa/>. Acesso em: 10 ago. 2020.

2 Agências distribuidoras de quadrinhos e que, por meio de acordos entre cartunistas e periódicos, distribuem HQ dentro e fora dos Estados Unidos. Nos anos 1930, existem cerca de 160 syndicates pelos Estados Unidos, distribuindo milhares de HQ para outros tantos milhares de jornais. Eles também eram responsáveis pela distribuição de notícias, anúncios publicitários e reportagens, entre outros conteúdos. A bibliografia específica segue escassa. Um bom panorama sobre uma das maiores agências distribuidoras encontra-se em Mullaney (2015).

3 FSA foi uma iniciativa criada em 1935 durante o governo Franklin Roosevelt. Nos marcos da política econômica do New Deal, procurou estabelecer políticas públicas de combate à pobreza no campo, sob a perspectiva de reconstrução do país. Destacaram-se as fotografias produzidas ao longo do projeto por nomes como Walker Evans, Dorothea Lange e Gordon Parks. Em comum, elas tinham a produção de imagens fotográficas que visavam despertar nas classes médias um empenho pela reconstrução do país (Lissovsky e Sá-Carvalho, 2008: 77-90).

4 Outra fotografia de Wolcott produzida no mesmo contexto segue orientação análoga. Nela se encontra uma mulher com uma criança de colo, num quarto forrado com imagens de celebridades reproduzidas em revistas e jornais. Cf. Marion Post Wolcott. Interior of Negro tenant's home on Marcella Plantation. Mileston, Mississippi Delta, Mississippi. Disponível em: <https://www.loc.gov/pictures/resource/fsa.8c10751//>. Acesso em: 22 ago. 2020.

5 Há reproduções dessa fotografia em redes sociais dedicadas a nostálgicos fãs de quadrinhos, como no Pinterest. Disponível em: <https://br.pinterest.com/pin/748019819347086662/>. Acesso em: 20 out. 2020. Ela se encontra catalogada no Centre for Creative Photography, ligado à Universidade do Arizona, conforme consta no seguinte catálogo, p. 74. Disponível em: $<$ https://ccp.arizona.edu/sites/default/files/cg-john-gutmann.pdf>. Acesso em: 20 out. 2020.

6 "Bem, eu não posso comentar sobre a imagem que as garotas tinham da Wonder Woman. Eu nunca soube que elas liam esta ou qualquer revista em quadrinhos. Que garotas tivessem uma preferência por meu tipo de literatura teria sido uma imagem bem mais assustadora para mim do que qualquer cena de um homem sendo surrado pela Wonder Woman" (Feiffer, 1965: 44).

70 caso à parte é, obviamente, Mulher-Maravilha, cuja história é analisada numa obra recente de Lepore (2014). É claro que a popularidade de Mulher Maravilha ajudou a man- 
ter a série no mercado, o que pode ser confirmado pelas heroínas que nele surgiram na esteira do sucesso da personagem criada por William Marston. Mas as razões contratuais envolvendo a DC Comics e seu criador, que estipulava que seus herdeiros recuperariam todos os direitos de posse da marca/personagem caso o título com o nome dela fosse descontinuado, certamente contribuíram para sua longa permanência nas bancas de revista (Gabilliet, 2010: 34-35).

\section{REFERÊNCIAS BIBLIOGRÁFICAS}

ARMSTRONG, N. Fiction in the age of photography: the legacy of British realism. Cambridge: Harvard University Press, 2002.

BEATY, B. Fredric Wertham and the critique of mass culture. Jackson: University Press of Mississipi, 2005.

BEATY, B. Comics versus art. Toronto: University of Toronto Press, 2012.

BECKER, H. Los mundos del arte. Sociología del trabajo artístico. Buenos Aires: Universidad Nacional de Quilmes, 2008.

BENJAMIN, W. Rua de mão única: Obras Escolhidas II. São Paulo Brasiliense, 1987.

BENTON, M. The comic book in America. Dallas: Taylor Publishing, 1989.

BOURDIEU, P. La fotografía: un arte intermedio. Mimeografado, s.d. Disponível em: <http://www.fts.uner.edu. ar/catedras03/tfoi/recursos/Bourdieu_LaFotografia.pdf>. Acesso em: 15 dez. 2014.

BURROWS, S. A familiar strangeness: American fiction and the language of photography, 1839-1945. Athens: University of Georgia Press, 2010.

CALVINO, Í. Seis propostas para o próximo milênio. São Paulo: Companhia das Letras, 1990.

CHAMBLISS, J.; SVITAVSKY, W. From pulp hero to superhero: culture, race, and identity in American culture, 1900-1940. Studies in American Culture, [S.I.], v. 30, n. 1, 2008.

DARNTON, R. O beijo de Lamourette: mídia, cultura e revolução. São Paulo: Companhia das Letras. 1990.

EISNER, W. The dreamer. New York: Norton \& Company, 2008.

FARM SECURITY ADMINISTRATION/OFFICE OF WAR INFORMATION PHOTOGRAPH COLLECTION. Disponíveis em: <http://www.loc.gov/pictures/collection/fsa/>. Acesso em: 22 ago. 2020.

FEIFFER, J. The great comic book heroes. New York: The Dial Press, 1965.

GABILLIET, J.-P. "Fun in four colors": comme la quadrichromie a créé la bande dessinée aux États-Units. Transatlantica, [S.I.], v. 4, n. 1, p. 1-8, 2005. https://doi.org/10.4000/transatlantica.319.

GABILLIET, J.-P. Of comics and men: a cultural history of American comic books. Jackson: University Press of Mississipi, 2010.

GORDON, I. Comic strips and consumer culture, 1890-1945. Washington: Smithsonian Institution Press, 1998. 
GROESTEEN, T. História em quadrinhos: essa desconhecida arte popular. João Pessoa: Marca de Fantasia, 2004.

GUTMANN, J. Kids Reading comics. San Francisco, 1938. Disponível em: <https://br.pinterest.com/ pin/748019819347086662/>. Acesso em: 20 out. 2020.

HAJDU, D. The ten-cent plague. The great comic book scare and how it changed

America. New York: Picador/Farrar, Straus and Giroux, 2009.

JOÃO DO RIO. Cinematógrafo: crônicas cariocas. Rio de Janeiro: ABL, 2009.

GUTMANN, J. Photograph Collection. Centre for Creative Photography. Disponível em: <https://ccp.arizona. edu/sites/default/files/cg-john-gutmann.pdf>. Acesso em: 20 out. 2020.

KRAUSS, R. When words fail. October, Cambridge v. 22, p. 91-103, set.-dez. 1982. https://doi. org/10.2307/778365.

LEPORE, J. The secret history of Wonder Woman. New York: Alfred A. Knopf, 2014.

LISSOVSKY, M.; SÁ-CARVALHO, C. Fotografia e representação do sofrimento. Revista Galáxia, n. 15, p. 77-90, jun. 2008.

LOPES, P. Demanding respect. The evolution of the American comic book. Philadelphia: Temple University Press, 2009.

MAUAD, A. M. Poses e flagrantes: ensaios sobre história e fotografias. Niterói: Universidade Federal Fluminense, 2008.

MILLER, H. Pesadelo refrigerado. São Paulo: Francis, 2006.

MULLANEY, D. (org.). King of the comics: 100 years of King Features Syndicate. San Diego: IDW Comics, 2015. NEWSDEALER, New York, jun. 1948.

PETRUCCI, A. Ler por ler: um futuro para a leitura. In: CHARTIER, R.; CAVALLO, G. (orgs.). História da leitura no mundo ocidental. São Paulo: Ática, 1999. p. 203-227.

POSTEMA, B. Narrative structure in comics: making sense of fragments. Rochester: RIT Press, 2013.

ROBBINS, T. The great women superheroes. In: HATFIELD, C.; HEER, J.; WORCESTER, K. (orgs.). The superhero reader. Jackson: University Press of Mississipi, 2013. p. 53-60.

RIESMAN, D.; GLAZER, N.; DENNEY, R. A multidão solitária: um estudo da mudança do caráter americano. 2. ed. São Paulo: Perspectiva, 1995.

SÜSSEKIND, F. Cinematógrafo de letras: literatura, técnica e modernização no Brasil. São Paulo: Companhia das Letras, 1987.

TAGG, J. The burden of representation: essays on photographies and histories. Minneapolis: University Press of Minnessota, 1993.

TIME \& LIFE. Life with classic comics: in praise of an American art form. Disponivel em: <https://time. com/22575/classic-comics-in-praise-of-an-american-art-/>. Acesso em: 15 ago. 2020. 
IVAN LIMA GOMES

WARSAW TIMES, Warsaw, Indiana, p. 14, sábado, 23 set. 1950.

WRIGHT, B. Comic book nation: the transformation of youth culture in America. Baltimore: The John Hopkins University Press, 2003.

ZORBAUGH, H. Editorial. Journal of Educational Sociology, Washington, v. 18, n. 4, p. 193-194, dez. 1944. 